Preprint

UCRL-JC- 137834

\title{
Selection of IFE Target Materials from a Safety and Environmental Perspective
}

J.F. Latkowski, S. Reyes, J. Sanz, J. Gomez del Rio

Lawrence

Livermore

National

Laboratory

This article was submitted to

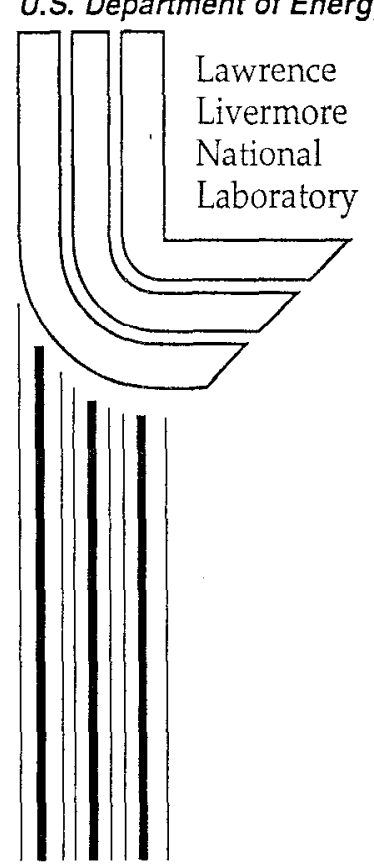

$13^{\text {th }}$ International Symposium on Heavy Ion Inertial Fusion, San Diego, CA, March 13-17, 2000

\section{March 1, 2000}




\section{DISCLAIMER}

This document was prepared as an account of work sponsored by an agency of the United States Government. Neither the United States Government nor the University of California nor any of their employees, makes any warranty, express or implied, or assumes any legal liability or responsibility for the accuracy, completeness, or usefulness of any information, apparatus, product, or process disclosed, or represents that its use would not infringe privately owned rights. Reference herein to any specific commercial product, process, or service by trade name, trademark, manufacturer, or otherwise, does not necessarily constitute or imply its endorsement, recommendation, or favoring by the United States Government or the University of California. The views and opinions of authors expressed herein do not necessarily state or reflect those of the United States Government or the University of California, and shall not be used for advertising or product endorsement purposes.

This is a preprint of a paper intended for publication in a journal or proceedings. Since changes may be made before publication, this preprint is made available with the understanding that it will not be cited or reproduced without the permission of the author.

This report has been reproduced directly from the best available copy.

Available to DOE and DOE contractors from the Office of Scientific and Technical Information

P.O. Box 62, Oak Ridge, TN 37831

Prices available from (423) 576-8401

http://apollo.osti.gov/bridge/

Available to the public from the National Technical Information Service

U.S. Department of Commerce

5285 Port Royal Rd.,

Springfield, VA 22161

http://www.ntis.gov/

OR

Lawrence Livermore National Laboratory

Technical Information Department's Digital Library

http://www.llnl.gov/tid/Library.html 


\title{
Selection of IFE target materials from a safety and environmental perspective
}

\author{
J. F. Latkowski ${ }^{\mathrm{a}, *}$, J. Sanz ${ }^{\mathrm{b}}, \mathrm{S}$. Reyes ${ }^{\mathrm{a}, \mathrm{b}}$, and J. Gomez del Rio ${ }^{\mathrm{b}}$ \\ "Lawrence Livermore National Laboratory \\ ${ }^{b}$ Universidad Nacional de Educacion a Distancia, Escuela Tecnica Superior Ingenieros Industriales, \\ Departamento Ingenieria Energetica, C/ Ciudad Universitaria, s/n, 28040 Madrid, Also: Instituto Fusion Nuclear, Madrid, Spain
}

\begin{abstract}
Target materials for inertial fusion energy (IFE) power plant designs might be selected for a wide variety of reasons including wall absorption of driver energy, material opacity, cost, and ease of fabrication. While each of these issues are of great importance, target materials should also be selected based upon their safety and environmental (S\&E) characteristics. The present work focuses on the recycling, waste management, and accident dose characteristics of potential target materials. If target materials are recycled so that the quantity is small, isotopic separation may be economically viable. Therefore, calculations have been completed for all stable isotopes for all elements from lithium to polonium. The results of these calculations are used to identify specific isotopes and elements that are most likely to be offensive as well as those most likely to be acceptable in terms of their S\&E characteristics.
\end{abstract}

Keywords: Inertial fusion energy; Safety and environment; Target design

\footnotetext{
* Corresponding author: Jeffery F. Latkowski Lawrence Livermore National Laboratory P. O. Box 808, Mailstop L-446

Livermore, CA 94550

Phone: (925) 423-9378/Fax: (925) 422-7390

E-mail: latkowski1@llnl.gov
} 


\section{Introduction}

The S\&E characteristics of IFE target materials may be divided into three main areas: ability to recycle, waste management, and accident safety. The analyses in this paper are used to identify materials that are most likely to be offensive as well as those most likely to be acceptable in terms of their S\&E characteristics. Since the quantity of target material is likely to be quite small $\left(<0.1 \mathrm{~m}^{3}\right.$ for a 1-week supply), it is assumed that isotopic separation may be an economically viable option for optimizing S\&E characteristics. Therefore, calculations have been completed for all stable isotopes from lithium to polonium. For this first evaluation of potential target materials, the results from each isotope are compared to a set of $S \& E$ criteria. Isotopes that are able to meet all three criteria show great potential. Those that fail to meet one or more of the criteria, however, may still be found to be acceptable following additional study with greater detail. The results presented here can guide future efforts to focus on those materials that merit further exploration.

\section{Safety and environmental criteria}

In order to divide the isotopes into groups that are more or less acceptable from an S\&E perspective, several criteria have been applied. These include contact dose rate, waste disposal rating, and approximate accident dose. A brief description of each is given below.

\subsection{Contact dose rate}

IFE power plants using indirect-drive targets will need to recycle the target materials due to the large quantities involved-about 1 ton of material per week. The contact dose rate of target materials is of importance, because it gives a sense of the difficulty of recycling. Although the exact methods of extraction and manufacturing will depend a great deal upon the specific materials and target design, most processes will share many of the same components. Examples include distance and force sensors, drive mechanisms, viewing systems, communication systems, electrical cables and connectors, and electronics for signal 
communications. The radiation dose that these components can tolerate and/or the cost of replacing the components will likely determine the feasibility of a given recycling process.

The European Fusion Technology Programme uses a lifetime dose limit of 30 MGy as a reference value for components subjected to high radiation fields [1]. Given that radiation hardened versions of many of the previously listed components are already capable of surviving doses of 1-20 MGy [2], it seems reasonable that 30 MGy may be achievable. If we arbitrarily declare that recycling plant equipment must survive for 30 years of continuous operation, we obtain a dose rate limit of $114 \mathrm{~Gy} / \mathrm{hr}$. The present work uses this value as one way of identifying those isotopes with desirable characteristics. A radioactive cooling time of 1 week is chosen, however, only a few isotopes would benefit from a time as long as 1 month. A study of the effects related to the selection of this cooling time (e.g., resource consumption, impurity levels in coolants, etc.) was performed by Lowenthal et al. [3].

\subsection{Waste disposal rating}

The concept of waste disposal rating (WDR) was introduced by Fetter et al. as a simple method for determining whether or not an activated fusion component would qualify for disposal via shallow land burial ("Class C") [4]. While laws do not yet exist for fusion radionuclides, radionuclide concentration limits may be calculated by following the methodology to 10 CFR 61 [5]. For each radionuclide of interest, the ratio of the calculated concentration to the limiting concentration is calculated. The WDR is the sum over all radionuclides. Only radionuclides with half-lives of $>5$ years are included in such waste disposal assessments.

A WDR less than unity indicates that material would qualify for disposal via shallow land burial given the current interpretation of the regulations. Although this is certainly a desirable outcome, it is not absolutely necessary. The disposal of small quantities of waste via deep geologic disposal may be possible and even cost-effective. In this work, we divide isotopes into those that would qualify for disposal via shallow land burial and those that would not.

\subsection{Accident dose potential}


Radiation doses, which would result from an accidental release from the power plant or target fabrication facility, are of interest. According to the Fusion Safety Standards, the dose to the most exposed individual at the site boundary (at $1 \mathrm{~km}$ ) must be shown to be $\leq 10 \mathrm{mSv}$ (1 rem) during an off-normal event [6]. This is based upon a 1991 Environmental Protection Agency document that specifies the level at which sheltering and evacuation should be undertaken [7]. This dose is a 50-year committed effective dose that only includes contributions from direct cloudshine and inhalation during plume passage, because they pose an immediate threat [6]. Doses from the groundshine and resuspension pathways are not normally counted against the $10 \mathrm{mSv}$ limit, since they are judged to be more a measure of the effectiveness of public health measures than of severity of the accident itself [6]. Nevertheless, the doses reported here include these additional pathways, and thus, should be viewed as conservative with respect to the $10 \mathrm{mSv}$ limit.

Accurate calculation of accident doses requires two key pieces of information. First, one must calculate dose conversion factors (in units of $\mathrm{Sv} / \mathrm{Bq}$ ) for each isotope. This step is relatively straight-forward and has been completed using the MACCS2 code [8]. Second, one must estimate the release fraction for each radionuclide of interest (radioactive isotopes produced from the neutron irradiation of the stable isotopes). This step requires detailed modeling of the accident as well as measurements of the material mobilization of under accident conditions. This has not been done in the present work. Instead, a very approximate set of release fractions have been assumed for a worst-case accident. These are the so-called "Piet" release fractions, and they depend solely upon the relative volatility of each element [9]. Although this is highly approximate, we feel that it is useful in that it sheds some light on the relative radiotoxicity of the isotopes. Future work should attempt to do a better job for this second step--at least for the isotopes that display the best characteristics or are the most likely to be used.

\section{Calculational process}

All neutron activation calculations use the neutron spectrum calculated for a reference target design [10]. The spectrum was calculated with the TART Monte Carlo particle transport code [11]. The target design includes the hohlraum, capsule, shields, and radiators. The hohlraum and shields would be coated with $\sim 40$ 
$\mu \mathrm{m}$ of high- $\mathrm{Z}$ material. A power plant using this target with a repetition rate of $5 \mathrm{~Hz}$ would consume $\sim 6.6$ $\times 10^{4} \mathrm{~cm}^{3}$ of high-Z material per week. For lead, this corresponds to a throughput of nearly 40 tons per year. The need for recycling is clear. Alternate target designs may have different quantities of material and slightly different locations, but the differences would not be great enough to affect the overall conclusions of this work. Once a particular target design and group of materials have been selected, more detailed calculations should be performed.

Neutron activation calculations have been completed with the ACAB98 radionuclide generation/depletion code [12]. Although ACAB allows one to model the pulsed nature (e.g., $5 \mathrm{~Hz}$ ) of the irradiation, calculations have been completed assuming a batch process in which the entire, 1-week inventory of material is irradiated at once. Thus, simulation of 30 years of irradiation required 1560 weekly pulses. $\mathrm{ACAB}$ was run (in an automated manner) a total of 264 times; once for each stable isotope from lithium to polonium. The same neutron spectrum has been used in each case, as the effect of a small quantity of target material would be small.

\section{Results}

All 264 isotopes were ranked according to their performance in each of three areas: contact dose rate, waste management, and accident dose potential. Next, we present a summary of the results in each area. Since the use of materials in IFE targets will depend upon their atomic numbers, results are presented for ranges of elements as well as for all 264 isotopes. Results are presented for the following ranges of atomic numbers (Z): 3-49 (lithium-indium), 50-59 (tin-praseodymium), 60-69 (neodymium-thullium), and 70-84 (ytterbium-polonium).

\subsection{Contact dose rate}

Out of 264 stable isotopes surveyed, 138 were able to meet the contact dose rate criterion of $<114 \mathrm{~Gy} / \mathrm{hr}$ after 7 days of radioactive decay. An additional 60 isotopes come within $10 x$ of the limit. This indicates that either added radiation tolerance and/or less conservatism (due to use of the semi-infinite medium 
approximation, contact dose rates are higher than the dose rate would be for a finite quantity of material) may be able to qualify additional isotopes for use based upon their dose rate. The contact dose rates ranged from $\sim 0$ (when contributions from tritium are discounted since it would be separated from the other target material) to $6.8 \times 10^{4} \mathrm{~Gy} / \mathrm{hr}\left(\sim 600 \times\right.$ grcater than the limit). ${ }^{89} \mathrm{Y}$ was the worst performer.

In terms of their acceptance based upon contact dose rate, acceptable isotopes are spread rather uniformly through the periodic table. Table 1 summarizes the results based upon ranges of atomic numbers. Of the 138 successful isotopes, 74 fall in the range $3 \leq Z \leq 49,17$ are in the range $50 \leq Z \leq 59,20$ are in the range $60 \leq Z \leq 69$, and 27 fall between 70 and 84 , inclusive.

\subsection{Waste disposal rating}

Even more isotopes were able to meet the waste disposal rating criterion of 1.0 . In all, 176 isotopes had WDR values $<1.0$. Twenty-nine isotopes have WDR values between 1.0 and 10 , and 25 isotopes fall in the range between 10 and $100 .{ }^{165} \mathrm{~Tb}$ was the worst performer at a value of $7.6 \times 10^{5}$. Table 1 shows the WDR results based upon ranges of atomic numbers. The distribution of isotopes that qualify based upon their WDR is not as well distributed as those that qualify based upon their contact dose rate. Specifically, only 10 isotopes with atomic numbers between 60 and 69 (inclusive) qualify based upon their WDR.

\subsection{Accident dose potential}

The process of calculating accident doses is more involved, and thus, was only performed for isotopes that met both the contact dose rate and waste disposal rating goals of $114 \mathrm{~Sv} / \mathrm{hr}$ and 1.0 , respectively. While 138 isotopes qualified based upon their contact dose rates and 176 isotopes qualified based upon their WDR, only 97 isotopes met these criteria simultaneously. Due to the non-uniform results for waste disposal, these 97 isotopes are also non-uniform as shown in Table 1. Specifically, only eight isotopes in the range $60 \leq \mathrm{Z} \leq 69$ meet both the contact dose rate and waste disposal criteria.

An estimate of the accident dose has been calculated for all 97 isotopes. It must be stressed that these results make use of the Piet release fractions, and thus, the doses are likely to be conservative. Actual 
release fractions need to be measured under simulated accident conditions. This work is intended to provide guidance for which isotopes have the greatest potential.

Of the 97 isotopes that satisfied both the contact dose rate and WDR criteria, 48 are able to meet the 10 $\mathrm{mSv}$ accident dose criterion. Table 2 lists these isotopes along with their contact dose rate, WDR, and accident dose results. An additional 23 isotopes come within an order of magnitude. The final 26 isotopes have accident dose estimates between 0.11 and $9.6 \mathrm{~Sv}$.

Among the 48 isotopes that are able to meet or exceed the criteria in all three categories, 22 have atomic numbers $<50$. Four isotopes fall between $Z=50$ and 59 , and seven are between 60 and 69 . Fifteen isotopes are in the critical range of $70 \leq Z \leq 84$. In this last range, an additional four isotopes come within $10 \times$ of the dose limit.

It is interesting to note that four of the $\mathrm{Hg}$ isotopes, which are particularly well-suited for separation from liquid Flibe [13], meet the dose rate and waste disposal criteria. Two of these isotopes - ${ }^{200} \mathrm{Hg}$ and ${ }^{201} \mathrm{Hg}$ also meet the accident dose criterion with estimated doses of 0.43 and $0.02 \mathrm{mSv}$, respectively. ${ }^{199} \mathrm{Hg}$ and

${ }^{202} \mathrm{Hg}$ have accident doses of 28 and $18 \mathrm{mSv}$, respectively, so they may be able to meet the requirement once actual measurements are made. These four isotopes account for $83 \%$ of natural $\mathrm{Hg}$, so its use would appear to ease the isotope separation requirements.

Other elements that might require only minimal isotopic separation include $\mathrm{Pb}, \mathrm{Hf}, \mathrm{Yb}, \mathrm{Nd}$, and $\mathrm{Pd}$. Elements that meet all three criteria without any isotopic separation include $\mathrm{Li}, \mathrm{Be}, \mathrm{B}$, and $\mathrm{C}$. This is good due to their likely presence in the actual capsule material. The three isotopes of lead that satisfy all three criteria account for $98.4 \%$ of natural $\mathrm{Pb}$. The three tungsten isotopes that satisfy the criteria account for $45 \%$ of the natural element. Acceptable $\mathrm{Hf}(3)$ and $\mathrm{Yb}(4)$ isotopes comprise $81 \%$ and $84 \%$ of their natural elements, respectively. $65 \%$ of natural $\mathrm{Nd}$ is able to meet all S\&E criteria. Finally, two isotopes that account for one-half of natural Pd meet the S\&E goals.

\section{Conclusions and future work}

A set of neutron activation calculations has been completed using the neutron spectrum within a typical heavy-ion fusion target. Given the small quantity of material needed for a 1-week supply of target material 
$\left(<0.1 \mathrm{~m}^{3}\right)$, isotopic separation may be a viable option, and thus, calculations have been performed for all stable isotopes from lithium to polonium. The neutron activation products for each isotope have been judged against a set of three safety and environmental criteria in the areas of contact dose rate (affects recycling), waste disposal rating (affects eventual disposal), and accident dose potential (affects safety of the target fabrication facility).

In all, 48 isotopes were able to meet the criteria in all three categories. Fifteen of these isotopes might be considered "high-Z" materials. An additional 23 isotopes are able to meet the contact dose rate and waste disposal criteria, while coming within an order of magnitude of the accident dose criterion. Since the radionuclide release fractions are highly approximate, these 23 isotopes may very well qualify once release fractions are measured under simulated accident conditions.

Among high- $\mathrm{Z}$ elements, lead is, by far, the best performer with three of its four isotopes able to meet all $\mathrm{S} \& \mathrm{E}$ criteria. The offensive isotope, ${ }^{204} \mathrm{~Pb}$ (fails to meet the contact dose rate criterion by $3.3 \times$ and the accident dose criterion by $11 \times$ ), accounts for only $1.4 \%$ of natural lead, so lead would require the least isotopic separation. Other favorable results include mercury, hafnium, and ytterbium, in which acceptable isotopes account for $36 \%, 81 \%$, and $84 \%$ of the natural elements, respectively.

Several low-Z elements are able to meet all three criteria without any isotopic separation (all isotopes meet all three criteria). These include lithium, beryllium, boron, and carbon. These elements are used in many capsule designs, so this is a favorable result.

Future work should focus on three main areas: estimation of radiation damage resistance of recycling and fabrication components, measurement of radionuclide release fractions under accident conditions, and expansion of the accident dose conversion factor data library.

A more detailed analysis of the target material recycling and fabrication process along with a better estimation of radiation damage limits for key (expensive or difficult to replace) components is needed. Such work may enable a relaxation of the $114 \mathrm{~Sv} / \mathrm{hr}$ ( 30 MGy over 30 year lifetime of the facility) dose rate criterion. If one could easily and inexpensively replace a particular component, the rest of the system may be able to tolerate significantly higher doses.

Accident dose conversion factors could only be calculated for about 290 radionuclides. While these certainly represent the most important radionuclides, it is prudent to verify that important radionuclides 
have not been overlooked. A survey of radionuclides that are produced in significant quantities has been completed and data will be collected for those judged to be of greatest importance. Additional MACCS2 calculations will be performed for these radionuclides.

Radionuclide release fractions are the key to accident dose estimation. Release fractions need to be measured for important elements under simulated accident conditions. This work should, at a minimum, be performed for lead and mercury due to their favorable S\&E characteristics and likely use as target materials.

\section{Acknowledgements}

This work was performed under the auspices of the U.S. Department of Energy by University of California Lawrence Livermore National Laboratory under contract No. W-7405-Eng-48 and under support of scholarship from UNED, Madrid, Spain.

\section{References}

[1] J. Benner and W. Till, Nucl. Eng. Int. 35 (1990) 38.

[2] R. Sharp and M. Decreton, Reliab. Engng. System Safety 53 (1996) 291.

[3] M. D. Lowenthal et al., Fusion Technol. 34 (1998) 619.

[4] S. A. Fetter, E. T. Cheng and F. M. Mann, Fusion Eng. Des. 13 (1990) 239.

[5] Code of Federal Regulations, U. S. Nuclear Regulatory Commission, Title 10, Part 61 (1999).

[6] U. S. Department of Energy Report DOE-STD-6003-96 (1996).

[7] U. S. Environmental Protection Agency Report PB92-164763 (1991).

[8] D. Chanin and M. L. Young, Sandia National Laboratory Report SAND97-0594 (1998).

[9] S. J. Piet, E. T. Cheng and L. J. Porter, Fusion Technol. 17 (1990) 636.

[10] J. G. Woodworth and W. R. Meier, Lawrence Livermore National Laboratory Report UCRL-JC-117396 (1995).

[11] D. E. Cullen, I awrence Livermore National Laboratory Repont UCRL-ID-126455, Rev. 2 (1998).

[12] J. Sanz, Universidad Nacional de Educacion a Distancia, Lawrence Livermore National Laboratory Report UCRL-CR-133040 (1999).

[13] R. W. Moir et al., Fusion Technol. 25 (1994) 5. 
Table 1

Number of isotopes able to meet the contact dose rate and waste disposal criteria

\begin{tabular}{llll}
$\begin{array}{l}\text { Range of atomic } \\
\text { numbers }\end{array}$ & $\begin{array}{l}\text { Contact } \\
\text { dose rate }\end{array}$ & $\begin{array}{l}\text { Waste } \\
\text { disposal } \\
\text { rating }\end{array}$ & Both \\
\hline $3 \leq \mathrm{Z} \leq 49$ & 74 & 91 & 50 \\
$50 \leq \mathrm{Z} \leq 59$ & 17 & 37 & 16 \\
$60 \leq \mathrm{Z} \leq 69$ & 20 & 10 & 8 \\
$70 \leq \mathrm{Z} \leq 84$ & 27 & 38 & 23 \\
Total & 138 & 176 & 97 \\
\hline
\end{tabular}


Table 2

Isotopes that meet criteria for contact dose rate ${ }^{1}$, waste disposal rating ${ }^{2}$, and accident dose ${ }^{3}$

\begin{tabular}{|c|c|c|c|}
\hline Isotope & $\begin{array}{l}\text { Contact dose } \\
\text { rate }(\mathrm{Gy} / \mathrm{hr})\end{array}$ & $\begin{array}{l}\text { Waste disposal } \\
\text { rating (unitless) }\end{array}$ & $\begin{array}{l}\text { Accident } \\
\text { dose (Sv) }\end{array}$ \\
\hline${ }^{6} \mathrm{Li}$ & $<1.0 \mathrm{E}-10$ & $<1.0 \mathrm{E}-10$ & $<1.0 \mathrm{E}-10$ \\
\hline${ }^{7} \mathrm{Li}$ & $<1.0 \mathrm{E}-10$ & $<1.0 \mathrm{E}-10$ & $<1.0 \mathrm{E}-10$ \\
\hline${ }^{9} \mathrm{Be}$ & $<1.0 \mathrm{E}-10$ & 2.2E-5 & $1.0 \mathrm{E}-7$ \\
\hline${ }^{10} \mathrm{~B}$ & $<1.0 \mathrm{E}-10$ & $7.3 \mathrm{E}-3$ & $3.4 \mathrm{E}-5$ \\
\hline${ }^{11} \mathrm{~B}$ & $<1.0 \mathrm{E}-10$ & $1.7 \mathrm{E}-3$ & $7.8 \mathrm{E}-6$ \\
\hline${ }^{12} \mathrm{C}$ & $<1.0 \mathrm{E}-10$ & $5.6 \mathrm{E}-8$ & $1.5 \mathrm{E}-10$ \\
\hline${ }^{13} \mathrm{C}$ & $<1.0 \mathrm{E}-10$ & $3.3 \mathrm{E}-2$ & $5.6 \mathrm{E}-5$ \\
\hline${ }^{16} \mathrm{O}$ & $<1.0 \mathrm{E}-10$ & $9.3 \mathrm{E}-4$ & $9.2 \mathrm{E}-8$ \\
\hline${ }^{20} \mathrm{Ne}$ & $<1.0 \mathrm{E}-10$ & $5.5 \mathrm{E}-3$ & $3.3 \mathrm{E}-4$ \\
\hline${ }^{2 !} \mathrm{Ne}$ & $3.5 \mathrm{E}-8$ & $1.6 \mathrm{E}-3$ & $7.7 \mathrm{E}-6$ \\
\hline${ }^{22} \mathrm{Ne}$ & $1.1 \mathrm{E}-2$ & $2.4 E-5$ & $1.2 \mathrm{E}-4$ \\
\hline${ }^{26} \mathrm{Mg}$ & $2.8 \mathrm{E}+0$ & $2.1 \mathrm{E}-4$ & $6.9 \mathrm{E}-3$ \\
\hline${ }^{49} \mathrm{Ti}$ & $7.3 \mathrm{E}+1$ & $7.7 \mathrm{E}-7$ & $6.2 \mathrm{E}-3$ \\
\hline${ }^{50} \mathrm{~V}$ & $3.5 E+1$ & $2.5 \mathrm{E}-9$ & $2.7 \mathrm{E}-3$ \\
\hline${ }^{53} \mathrm{Cr}$ & $3.9 \mathrm{E}+0$ & $<1.0 \mathrm{E}-10$ & $4.2 \mathrm{E}-3$ \\
\hline${ }^{54} \mathrm{Cr}$ & $7.75 \mathrm{E}-1$ & $<1.0 \mathrm{E}-10$ & $2.2 \mathrm{E}-4$ \\
\hline${ }^{74} \mathrm{Ge}$ & $1.9 \mathrm{E}+0$ & $<1.0 \mathrm{E}-10$ & $8.4 \mathrm{E}-4$ \\
\hline${ }^{84} \mathrm{Kr}$ & $5.7 \mathrm{E}+0$ & $3.4 \mathrm{E}-3$ & $7.7 \mathrm{E}-4$ \\
\hline${ }^{97} \mathrm{Mo}$ & $4.6 E+0$ & $5.4 \mathrm{E}-\mathrm{l}$ & $4.0 \mathrm{E}-3$ \\
\hline${ }^{105} \mathrm{Pd}$ & $2.2 \mathrm{E}+1$ & $9.1 \mathrm{E}-2$ & 1.2E-3 \\
\hline${ }^{106} \mathrm{Pd}$ & $4.2 \mathrm{E}+1$ & $2.1 \mathrm{E}-2$ & $8.6 \mathrm{E}-4$ \\
\hline${ }^{113} \mathrm{Cd}$ & $1.4 \mathrm{E}+0$ & $8.9 \mathrm{E}-2$ & $1.1 \mathrm{E}-3$ \\
\hline${ }^{115} \mathrm{Sn}$ & $7.1 \mathrm{E}+1$ & $2.2 \mathrm{E}-4$ & $7.6 \mathrm{E}-3$ \\
\hline${ }^{117} \mathrm{Sn}$ & $9.0 \mathrm{E}+1$ & $8.2 \mathrm{E}-8$ & $1.9 \mathrm{E}-3$ \\
\hline${ }^{139} \mathrm{La}$ & $1.1 \mathrm{E}+2$ & $7.2 \mathrm{E}-1$ & $9.8 \mathrm{E}-3$ \\
\hline${ }^{141} \mathrm{Pr}$ & $1.0 \mathrm{E}+1$ & $3.1 \mathrm{E}-3$ & $4.5 \mathrm{E}-3$ \\
\hline${ }^{142} \mathrm{Nd}$ & $9.9 \mathrm{E}-1$ & $6.7 \mathrm{E}-5$ & $7.3 \mathrm{E}-4$ \\
\hline${ }^{143} \mathrm{Nd}$ & $8.2 \mathrm{E}-2$ & $1.1 \mathrm{E}-6$ & $9.5 \mathrm{E}-5$ \\
\hline${ }^{145} \mathrm{Nd}$ & $4.8 \mathrm{E}-2$ & $4.4 \mathrm{E}-9$ & $2.2 \mathrm{E}-5$ \\
\hline${ }^{146} \mathrm{Nd}$ & $1.4 \mathrm{E}+1$ & $2.0 \mathrm{E}-10$ & $3.2 \mathrm{E}-3$ \\
\hline${ }^{155} \mathrm{Gd}$ & $2.7 \mathrm{E}+1$ & $1.9 \mathrm{E}-2$ & $1.6 \mathrm{E}-3$ \\
\hline${ }^{156} \mathrm{Gd}$ & $7.3 \mathrm{E}+1$ & $5.5 \mathrm{E}-3$ & $1.7 \mathrm{E}-4$ \\
\hline${ }^{163}$ Dy & $1.4 \mathrm{E}-2$ & $3.6 \mathrm{E}-1$ & $4.5 \mathrm{E}-6$ \\
\hline${ }^{171} \mathrm{Yb}$ & $3.1 \mathrm{E}+1$ & $1.4 \mathrm{E}-1$ & $2.0 \mathrm{E}-4$ \\
\hline${ }^{172} \mathrm{Yb}$ & $6.4 \mathrm{E}+0$ & $1.1 \mathrm{E}-2$ & $2.5 \mathrm{E}-5$ \\
\hline${ }^{173} \mathrm{Yb}$ & $3.6 \mathrm{E}-1$ & $4.1 \mathrm{E}-4$ & $8.7 E-6$ \\
\hline${ }^{174} \mathrm{Yb}$ & $2.9 \mathrm{E}+0$ & $6.2 \mathrm{E}-6$ & $6.7 E-5$ \\
\hline${ }^{177} \mathrm{Hf}$ & $8.2 E+1$ & 1.7E-3 & $2.1 \mathrm{E}-5$ \\
\hline${ }^{178} \mathrm{Hf}$ & $2.4 \mathrm{E}+0$ & $1.2 \mathrm{E}-1$ & $2.0 \mathrm{E}-6$ \\
\hline${ }^{180} \mathrm{Hf}$ & $1.1 \mathrm{E}+2$ & $9.9 \mathrm{E}-2$ & $4.8 \mathrm{E}-3$ \\
\hline${ }^{180} \mathrm{~W}$ & $1.0 \mathrm{E}+1$ & $9.9 \mathrm{E}-2$ & $3.6 \mathrm{E}-3$ \\
\hline${ }^{383} W$ & $1.3 E+1$ & $1.8 \mathrm{E}-4$ & $2.3 \mathrm{E}-3$ \\
\hline${ }^{184} W$ & $1.6 \mathrm{E}+1$ & $1.4 \mathrm{E}-3$ & $9.6 \mathrm{E}-3$ \\
\hline${ }^{200} \mathrm{Hg}$ & $6.7 \mathrm{E}-2$ & $1.2 \mathrm{E}-7$ & $4.3 \mathrm{E}-4$ \\
\hline${ }^{201} \mathrm{Hg}$ & $4.9 \mathrm{E}-3$ & $2.0 \mathrm{E}-9$ & $1.8 \mathrm{E}-5$ \\
\hline${ }^{206} \mathrm{pb}$ & $3.2 \mathrm{E}-1$ & $4.5 \mathrm{E}-5$ & $6.8 \mathrm{E}-4$ \\
\hline${ }^{207} \mathrm{~Pb}$ & $2.5 \mathrm{E}-2$ & $6.6 \mathrm{E}-6$ & $1.2 \mathrm{E}-4$ \\
\hline${ }^{208} \mathrm{~Pb}$ & $4.2 \mathrm{E}-3$ & $3.3 \mathrm{E}-1$ & $3.3 \mathrm{E}-5$ \\
\hline
\end{tabular}

Contact dose rate goal is $\leq 114 \mathrm{~Gy} / \mathrm{hr}$

${ }^{2}$ Waste disposal rating goal is $\leq 1.0$

${ }^{3}$ Accident dose goal is $\leq 10^{-2} \mathrm{~Sv}$ 
